\title{
Impact of Consciousness Energy Healing Treatment on the Isotopic Abundance Ratio of Folic Acid
}

\author{
Dahryn Trivedii ${ }^{1}$, Mahendra Kumar Trivedi ${ }^{1}$, Alice Branton ${ }^{1}$, Snehasis Jana ${ }^{2 *}$ \\ ${ }^{1}$ Trivedi Global Inc, Henderson, USA \\ ${ }^{2}$ Trivedi Science Research Laboratory Pvt Ltd, India
}

Submission: January 21, 2021; Published: February 09, 2021

*Corresponding author: Snehasis Jana, Trivedi Science Research Laboratory Pvt Ltd., Thane (W), Maharashtra, India

Abstract

Folic acid (Vitamin $\mathrm{B}_{9}$ ) is the water-soluble vitamin mainly found in the foods and supplements, which is involved in the synthesis and repair of DNA and RNA, aiding rapid cell division and growth, enhancing the overall brain health, etc. in the body. In this study, the impact of the Trivedi Effect ${ }^{\circledR}$-Consciousness Energy Healing Treatment on the structural properties and the isotopic abundance ratio of folic acid was investigated using LC-MS spectroscopy. The test sample folic acid was divided into control and treated parts. Only the treated part received the Trivedi Effect ${ }^{\circledR}$-Consciousness Energy Healing Treatment remotely by a renowned Biofield Energy Healer, Dahryn Trivedi. The chromatographic spectra of both the samples exhibited the same retention time at 1.8 minutes and mass of the molecular ion peak at 441.92 (calcd for $\mathrm{C}_{19} \mathrm{H}_{20} \mathrm{~N}_{7} \mathrm{O}_{6}{ }^{+}, 442.15$ ) along with low molecular fragmented mass peaks at $m / z 295.08,267,250.17$, and 207.92 for $\mathrm{C}_{14} \mathrm{H}_{11} \mathrm{~N}_{6} \mathrm{O}_{2}{ }^{+}, \mathrm{C}_{12} \mathrm{H}_{15} \mathrm{~N}_{2} \mathrm{O}_{5}{ }^{+}, \mathrm{C}_{12} \mathrm{H}_{12} \mathrm{NO}_{5}{ }^{+}$, and $\mathrm{C}_{11} \mathrm{H}_{14} \mathrm{NO}_{3}{ }^{+}$, respectively were also observed. The peak area of the treated folic acid (6029494.3) was increased by $1.12 \%$ compared to the control sample (5963001.45).

The isotopic abundance ratio of $\mathrm{P}_{\mathrm{M}+1} / \mathrm{P}_{\mathrm{M}}\left({ }^{2} \mathrm{H} /{ }^{1} \mathrm{H}\right.$ or ${ }^{13} \mathrm{C} /{ }^{12} \mathrm{C}$ or ${ }^{15} \mathrm{~N} /{ }^{14} \mathrm{~N}$ or $\left.{ }^{17} \mathrm{O} /{ }^{16} \mathrm{O}\right)$ in the treated folic acid was significantly increased by $81.37 \%$ compared with the control sample. Hence, the ${ }^{13} \mathrm{C},{ }^{2} \mathrm{H},{ }^{15} \mathrm{~N}$, and ${ }^{17} \mathrm{O}$ contributions from $\mathrm{C}_{19} \mathrm{H}_{20} \mathrm{~N}_{7} \mathrm{O}_{6}{ }^{+}$to $m / z$ 442.92 in the treated sample were significantly increased compared with the control sample. The changes in isotopic abundance and mass peak intensities might occur due to the changes in nuclei possibly through the interference of neutrino particles via the Trivedi Effect ${ }^{\circledR}$-Consciousness Energy Healing Treatment. The increased isotopic abundance ratio and peak area of the treated folic acid may increase the chemical bond strength, increase its stability, improve solubility, and bioavailability in the body. The new form of Biofield Energy Treated folic acid could be used for designing novel pharmaceutical formulations that might offer better therapeutic response against embryonic defects, clinical depression, megaloblastic anemia, altered memory, and brain function, leuco- and thrombocytopenia, malignancies, neural tube defects, depression, allergic diseases, cardiovascular disease, and lower bone density, etc.

Keyword: Folic acid; The Trivedi effect ${ }^{\circledR ;}$ Biofield energy; Consciousness energy healing treatment; LC-MS

\section{Introduction}

Folic acid (Vitamin $\mathrm{B}_{9}$ ) is the water-soluble vitamin mainly found in the foods and supplements [1]. Daily recommended folate for adults is 400 micrograms ( $\mathrm{mcg}$ ) and for women in pregnancy is 400 to $800 \mathrm{mcg}$ of folic acid a day [2]. The folate is highly rich in the food items, i.e., dark green leafy vegetables, fruits, avocado, nuts, chickpeas, soybeans, beetroot, spinach, liver, asparagus, yeast, kale, dairy products, Brussels sprouts, poultry and meat, eggs, seafood, grains, and some beers [3-6]. Folic acid plays many physiological functions in the body, i.e., various intracellular reactions, enzymatic reactions included in vitamin metabolism and amino acid synthesis. It is majorly involved in the synthesis and repair of DNA and RNA, aiding rapid cell division and growth, enhancing the overall brain health, and in age-related hearing loss [7]. Along with this, folic acid also plays 
important role in normal blood formation, normal metabolism of the immune system, normal amino acid synthesis, homocysteine levels, cell division, control various psychological functions, maintain normal maternal tissue growth during pregnancy, reduction of tiredness and fatigue. The deficiency of folic acid might result from inadequate intake, defective absorption (i.e., Crohn's disease or celiac disease), abnormal metabolism or increased requirements during pregnancy or breastfeeding, some genetic disorders, certain medicines (i.e., phenytoin, sulfasalazine, etc.), alcohol consumption, etc. Its deficiency may cause glossitis, diarrhoea, depression, confusion, anemia, grey hair, mouth sores, poor growth, congenital deformities, swollen tongue, embryonic defects, altered memory and brain function, cardiovascular disease, leuco- and thrombocytopenia, particular neural tube defects, and malignancies, long-term risk of lower bone density, higher risk of potentially developing allergic diseases, etc. [8-10].

The solubility of folic acid is very poor $(1.6 \mathrm{mg} / \mathrm{L}$ in water). It is heat sensitive and decompose rapidly in the presence of light [11]. Thus, the physicochemical properties of folic acid are very important while preparing the nutraceutical and pharmaceutical formulations in the pharmaceutical industries. Some of the recent scientific experiments proved that the Trivedi Effect $^{\circledR}$-Consciousness Energy Healing Treatment has improved the physicochemical properties, isotopic abundance, and bioavailability of many pharmaceutical/nutraceutical compounds [12-14]. The Trivedi Effect ${ }^{\circledR}$ is a natural and only scientifically proven phenomenon in which an individual can harness this energy from the "Universe" and transmit it anywhere on the planet via the possible mediation of neutrinos [15]. Every living being possesses a unique infinite and para-dimensional electromagnetic energy field surrounding the body known as "Biofield". Energy Therapies accepted worldwide nowadays against various disease conditions and for better health and wellness [16-18]. Biofield Energy Healing therapy is recognized as a Complementary and Alternative Medicine (CAM) by the National Center of Complementary and Integrative Health $(\mathrm{NCCIH})$ with other therapies, medicines, and practices such as traditional Chinese herbs and medicines, Ayurvedic medicine, aromatherapy, homeopathy, yoga, Tai Chi, Qi Gong, chiropractic/osteopathic manipulation, meditation, acupressure, acupuncture, hypnotherapy, Reiki, healing touch, movement therapy, naturopathy, cranial sacral therapy, etc. [19]. These CAM therapies have been adopted by most of the U.S.A. population [20]. The Trivedi Effect ${ }^{\circledR}{ }^{\circledR}$-Consciousness Energy Healing Treatment also has the significant impact on the transformation of metals, ceramics, and polymer [21-23], organic compounds [24], microorganisms $[25,26]$ the productivity of crops $[27,28]$ and cancer cells $[29,30]$.

To understand the isotope effects resulting from the alterations of the isotopic composition, the study on the natural stable isotope ratio analysis has many applications in the different field of sciences [31-33]. The sophisticated techniques like gas chromatography-mass spectrometry (GC-MS) and liquid chromatography-mass spectrometry (LC-MS), are widely used for the analysis of isotope ratio with sufficient precision [32]. Therefore, the LC-MS based structural characterization and the isotopic abundance ratio of $\mathrm{P}_{\mathrm{M}+1} / \mathrm{P}_{\mathrm{M}}\left({ }^{2} \mathrm{H} /{ }^{1} \mathrm{H}\right.$ or ${ }^{13} \mathrm{C} /{ }^{12} \mathrm{C}$ or $\left.{ }^{17} \mathrm{O} /{ }^{16} \mathrm{O}\right)$ in the Trivedi Effect ${ }^{\circledR}$-Consciousness Energy Healing Treated folic acid was performed compared to the control sample.

\section{Materials and Methods}

\section{Chemicals and eeagents}

The test sample folic acid was purchased from Alfa Aesar, India. Similarly, other chemicals and solvents used in the experiments also purchased in India.

\section{Consciousness energy healing treatment strategies}

The test sample folic acid powder sample was divided into control and treated parts. The control sample did not receive the Biofield Energy Treatment. But the control sample was treated with a "sham" healer who did not have any knowledge about the Biofield Energy and its treatment. However, the treated part of folic acid has received the Trivedi Effect ${ }^{\circledR}$-Consciousness Energy Healing Treatment remotely for 3 minutes under standard laboratory conditions by a well-known Biofield Energy Healer, Dahryn Trivedi, USA. Finally, both the samples were kept in sealed conditions and characterized using LC-MS analytical techniques.

\section{Characterization}

Liquid chromatography-mass spectrometry (LC-MS) Analysis and calculation of isotopic abundance ratio: The LC-MS analysis of both the samples of folic acid was carried out with the help of LC-MS Thermo Fisher Scientific, USA equipped with an ion trap detector connected with a triple-stage quadrupole mass spectrometer. Thermo Scientific Synchronis C18 (Length-250mm X ID 4.6mm X 5 micron) reversed phase column was used, which maintained at $25^{\circ} \mathrm{C}$. The methanol and water (1:1) were used as a diluent for sample preparation. The injection volume was $10 \mu \mathrm{L}$ and the analyte was eluted using acetonitrile $+10 \mathrm{mM}$ ammonium acetate (85:15) pumped at a constant flow rate of $1 \mathrm{~mL} / \mathrm{min}$ (total run time was $10 \mathrm{~min}$ ). Peaks were monitored at $220 \mathrm{~nm}$ using the PDA detector. The mass spectrometric analysis was performed under ESI +ve ion mode. The natural abundance of each isotope $(\mathrm{H}, \mathrm{C}, \mathrm{N}$, and $\mathrm{O}$ ) can be predicted from the comparison of the height of the isotope peak with respect to the base peak. The values of the natural isotopic abundance of the common elements are obtained from the literature [33-36]. The LC-MS based isotopic abundance ratio $\left(\mathrm{P}_{\mathrm{M}+1} / \mathrm{P}_{\mathrm{M}}\right)$ for the control and treated folic acid was calculated. The change in the isotopic abundance ratio was calculated using the following equation.

(\%) Change in isotopic abundance ratio $=\left[\left(\mathrm{IAR}_{\text {Treated }}-\right.\right.$ $\mathrm{IAR}_{\text {Control }} \mathrm{J} / \mathrm{IAR}_{\text {Control }} \mathrm{X}$ x 100]

Where $\mathrm{IAR}_{\text {Treated }}$ and $\mathrm{IAR}_{\text {Control }}$ were the isotopic abundance ratio in the treated and control folic acid. 


\section{Results and Discussion}

\section{Liquid Chromatography-Mass Spectrometry (LC-MS)}

The LC-MS chromatograms of both the folic acid samples showed the major peak at retention time $\left(R_{t}\right)$ of 1.8 minutes (Figure 1). The peak area near $\mathrm{R}_{\mathrm{t}} 1.8$ minutes of the Biofield Energy Treated folic acid (6029494.3) was increased by $1.12 \%$ compared to the control sample (5963001.45). The increased peak area of the Biofield Energy Treated folic acid indicated that the solubility of folic acid was increased after the Trivedi Effect ${ }^{\circledR}$-Consciousness Energy Healing Treatment. The solubility of folic acid is very poor and a major problem. Thus, the Biofield Energy Treated folic acid would be more soluble, bioavailable, and more efficacious nutraceutical and pharmaceutical formulations. The mass spectra of the control and Biofield Energy Treated samples corresponding to the $\mathrm{R}_{\mathrm{t}} 1.8$ minutes exhibited the existence of the molecular ion of folic acid $\left(\mathrm{C}_{19} \mathrm{H}_{20} \mathrm{~N}_{7} \mathrm{O}_{6}^{+}\right)$adduct with hydrogen ion (Figure 2) at $\mathrm{m} / \mathrm{z}$ 441.92 (calcd for $\mathrm{C}_{19} \mathrm{H}_{20} \mathrm{~N}_{7} \mathrm{O}_{6}{ }^{+}, 442.15$ ) along with the fragmented mass peaks at $m / z 295.08,267,250.17$, and 207.92 for $\mathrm{C}_{14} \mathrm{H}_{11} \mathrm{~N}_{6} \mathrm{O}_{2}^{+}$, $\mathrm{C}_{12} \mathrm{H}_{15} \mathrm{~N}_{2} \mathrm{O}_{5}{ }^{+}, \mathrm{C}_{12} \mathrm{H}_{12} \mathrm{NO}_{5}{ }^{+}$and $\mathrm{C}_{11} \mathrm{H}_{14} \mathrm{NO}_{3}{ }^{+}$were observed in both the sample (Figures $2 \& 3$ ). The experimental data were well matched with the literature data [37].
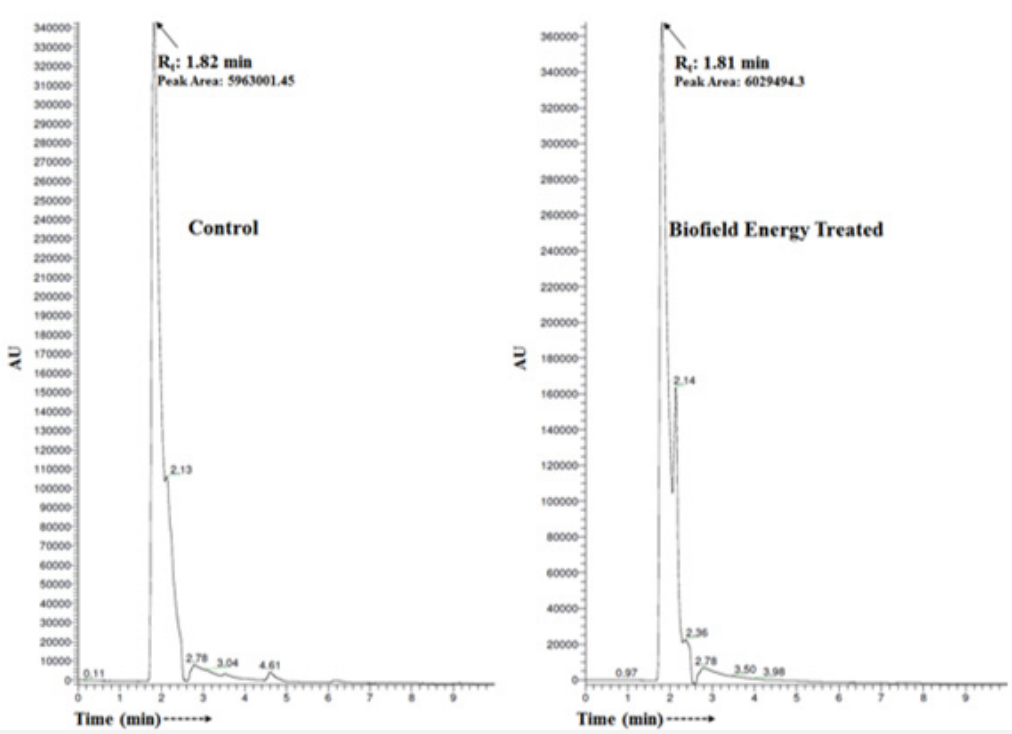

Figure 1: Liquid chromatograms of the control and Biofield Energy Treated folic acid.
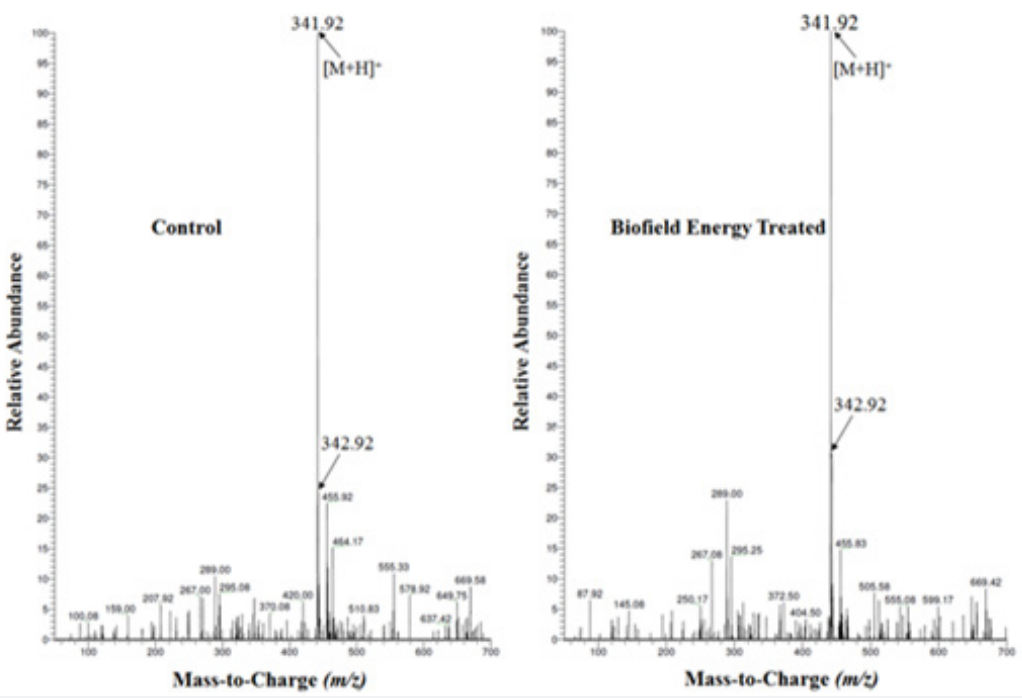

Figure 2: Mass spectra of the control and Biofield Energy Treated folic acid at $R_{t} 1.8$ minutes. 


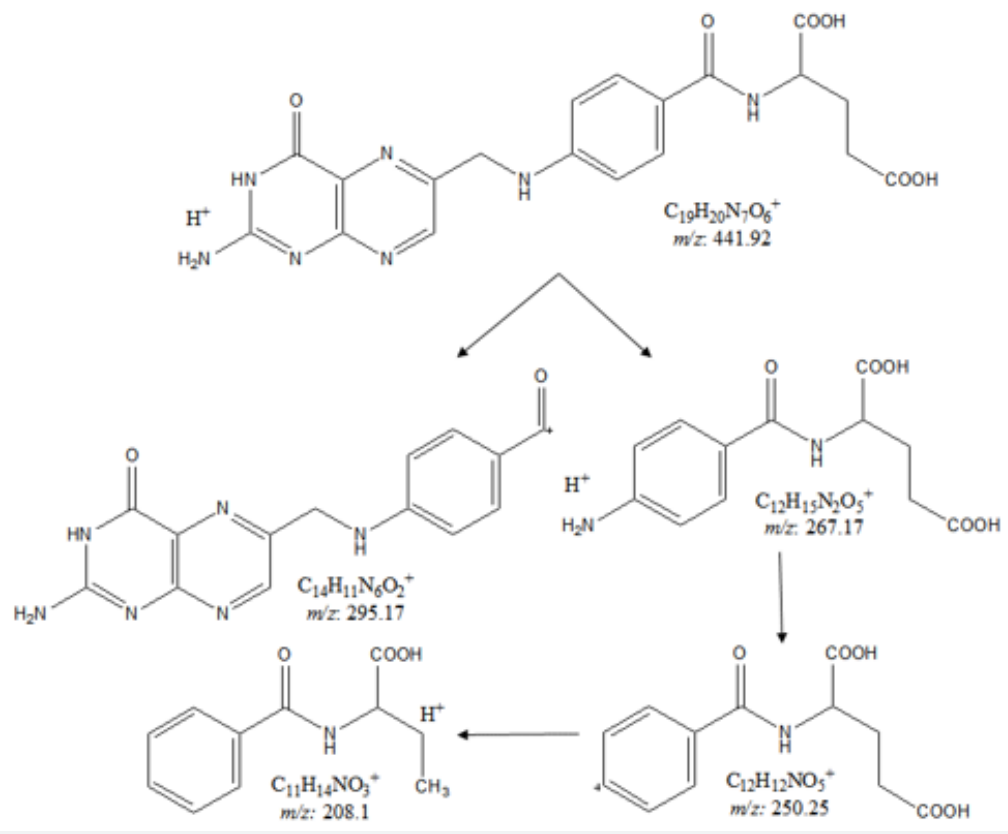

Figure 3: Proposed fragmentation pattern of folic acid.

\section{Isotopic abundance ratio analysis}

Both the folic acid samples showed the mass of a molecular ion at $m / z 441.92$ (calcd for $\mathrm{C}_{19} \mathrm{H}_{20} \mathrm{~N}_{7} \mathrm{O}_{6}{ }^{+}, 442.15$ ) with $100 \%$ relative abundance in the spectra. The theoretical calculation of isotopic peak $\mathrm{P}_{\mathrm{M}+1}$ for the protonated folic acid presented as below:

$\mathrm{P}\left({ }^{13} \mathrm{C}\right)=\left[(19 \times 1.1 \%) \times 100 \%\right.$ (the actual size of the $\mathrm{M}^{+}$peak $\left.)\right]$ / $100 \%=20.9 \%$

$$
\begin{aligned}
& \mathrm{P}\left({ }^{2} \mathrm{H}\right)=[(20 \times 0.015 \%) \times 100 \%] / 100 \%=0.3 \% \\
& \mathrm{P}\left({ }^{15} \mathrm{~N}\right)=[(7 \times 0.4 \%) \times 100 \%] / 100 \%=2.8 \% \\
& \mathrm{P}\left({ }^{17} \mathrm{O}\right)=[(6 \times 0.04 \%) \times 100 \%] / 100 \%=0.24 \% \\
& \mathrm{P}_{\mathrm{M}+1} \text { i.e. }{ }^{13} \mathrm{C},{ }^{2} \mathrm{H},{ }^{15} \mathrm{~N} \text {, and }{ }^{17} \mathrm{O} \text { contributions from } \mathrm{C}_{19} \mathrm{H}_{20} \mathrm{~N}_{7} \mathrm{O}_{6}+\text { to }
\end{aligned}
$$

$m / z 442.92=24.24 \%$

The calculated isotopic abundance of $\mathrm{P}_{\mathrm{M}+1}$ value $24.24 \%$ was higher to the experimental value (16.1\%) (Table 1). From the above calculation, it has been found that ${ }^{13} \mathrm{C}$ and ${ }^{15} \mathrm{~N}$ have the major contribution to $m / z$ 442.92. The LC-MS based isotopic abundance ratio analysis $\mathrm{P}_{\mathrm{M}}$ and $\mathrm{P}_{\mathrm{M}+1}$ for folic acid at $m / z 441.92$ and 442.92, respectively of both the samples, which were obtained from the observed relative peak intensities of $\left[\mathrm{M}^{+}\right]$and $\left[(\mathrm{M}+1)^{+}\right]$ peaks, respectively in the ESI-MS spectra (Table 1). The isotopic abundance ratio of $\mathrm{P}_{\mathrm{M}+1} / \mathrm{P}_{\mathrm{M}}\left({ }^{2} \mathrm{H} /{ }^{1} \mathrm{H}\right.$ or ${ }^{13} \mathrm{C} /{ }^{12} \mathrm{C}$ or ${ }^{15} \mathrm{~N} /{ }^{14} \mathrm{~N}$ or $\left.{ }^{17} \mathrm{O} /{ }^{16} \mathrm{O}\right)$ in treated folic acid was significantly increased by $81.37 \%$ compared to the control sample (Table 1). Thus, the ${ }^{13} \mathrm{C},{ }^{2} \mathrm{H},{ }^{15} \mathrm{~N}$ and

\begin{tabular}{|c|c|c|}
\hline Parameter & Control Sample & Biofield Energy Treated Sample \\
\hline $\mathrm{P}_{\mathrm{M}}$ at $m / z 441.92(\%)$ & 100 & 100 \\
\hline $\mathrm{P}_{\mathrm{M}+1}$ at $m / z 442.92(\%)$ & 16.1 & 29.2 \\
\hline $\mathrm{P}_{\mathrm{M}+1} / \mathrm{P}_{\mathrm{M}}$ & 0.16 & 0.29 \\
\hline $\begin{array}{l}\% \text { Change of isotopic abundance ratio }\left(\mathrm{P}_{\mathrm{M}+1} / \mathrm{P}_{\mathrm{M}}\right) \text { with respect } \\
\text { to the control sample }\end{array}$ & & 81.37 \\
\hline
\end{tabular}
${ }^{17} \mathrm{O}$ contributions from $\mathrm{C}_{19} \mathrm{H}_{20} \mathrm{~N}_{7} \mathrm{O}_{6}^{+}$to $\mathrm{m} / \mathrm{z} 442.92$ in the treated folic acid was increased compared to the control sample.

Table 1: LC-MS based isotopic abundance analysis results in Biofield Energy Treated folic acid compared to the control sample.

$\mathrm{P}_{\mathrm{M}}$ : the relative peak intensity of the parent molecular ion $\left[\mathrm{M}^{+}\right] ; \mathrm{P}_{\mathrm{M}+1}$ : the relative peak intensity of the isotopic molecular ion $\left[(\mathrm{M}+1)^{+}\right], \mathrm{M}:$ mass of the parent molecule.

LC-MS study confirmed the structure of folic acid. The isotopic abundance ratio of $\mathrm{P}_{\mathrm{M}+1} / \mathrm{P}_{\mathrm{M}}\left({ }^{2} \mathrm{H} /{ }^{1} \mathrm{H}\right.$ or ${ }^{13} \mathrm{C} /{ }^{12} \mathrm{C}$ or $\left.{ }^{17} \mathrm{O} /{ }^{16} \mathrm{O}\right)$ in the Biofield Energy Treated folic acid was significantly increased compared to the control sample. The altered isotopic composition in the Consciousness Energy Healing Treated folic acid might have altered the neutron to proton ratio in the nucleus via the possible mediation of neutrino. Neutrinos have the properties to change identities which interchange from one phase to another 
internally. The neutrinos have the ability to interact with protons and neutrons in the nucleus, which indicated a close relationship between neutrino and the isotope formation [15,32,33]. The isotopic abundance ratios ${ }^{2} \mathrm{H} /{ }^{1} \mathrm{H}$ or ${ }^{13} \mathrm{C} /{ }^{12} \mathrm{C}$ or ${ }^{17} \mathrm{O} /{ }^{16} \mathrm{O}$ would highly influence the atomic bond vibration of treated folic acid [38]. The increased isotopic abundance ratio and peak area of the Consciousness Energy Healing Treated folic acid may increase the chemical bond strength, increase its stability, more soluble, and bioavailability in the body. The Biofield Energy Treated folic acid would be more efficacious for the prevention and treatment of various diseases such as embryonic defects, clinical depression, megaloblastic anemia, altered memory and brain function, leuco- and thrombocytopenia, malignancies, neural tube defects, depression, allergic diseases, cardiovascular disease, and lower bone density, etc.

\section{Conclusion}

The Trivedi Effect ${ }^{\circledR}$-Consciousness Energy Healing Treatment showed a significant impact on the isotopic abundance ratio of folic acid. The chromatographic spectra of both the samples at retention time 1.8 minutes exhibited the mass of the molecular ion peak at 441.92 (calcd for $\mathrm{C}_{19} \mathrm{H}_{20} \mathrm{~N}_{7} \mathrm{O}_{6}^{+}, 442.15$ ) along with low molecular fragmented mass peaks at $m / z$ 295.08, 267, 250.17, and 207.92 for $\mathrm{C}_{14} \mathrm{H}_{11} \mathrm{~N}_{6} \mathrm{O}_{2}{ }^{+}, \mathrm{C}_{12} \mathrm{H}_{15} \mathrm{~N}_{2} \mathrm{O}_{5}{ }^{+}, \mathrm{C}_{12} \mathrm{H}_{12} \mathrm{NO}_{5}{ }^{+}$, and $\mathrm{C}_{11} \mathrm{H}_{14} \mathrm{NO}_{3}{ }^{+}$, respectively were also observed. The peak area of the Consciousness Energy Healing Treated folic acid was increased by $1.12 \%$ compared to the control sample. The isotopic abundance ratio of $\mathrm{P}_{\mathrm{M}+1} /$ $\mathrm{P}_{\mathrm{M}}\left({ }^{2} \mathrm{H} /{ }^{1} \mathrm{H}\right.$ or ${ }^{13} \mathrm{C} /{ }^{12} \mathrm{C}$ or ${ }^{15} \mathrm{~N} /{ }^{14} \mathrm{~N}$ or $\left.{ }^{17} \mathrm{O} /{ }^{16} \mathrm{O}\right)$ in the treated folic acid was significantly increased by $81.37 \%$ compared with the control sample. Hence, the ${ }^{13} \mathrm{C},{ }^{2} \mathrm{H},{ }^{15} \mathrm{~N}$ and ${ }^{17} \mathrm{O}$ contributions from $\mathrm{C}^{19} \mathrm{H}^{20} \mathrm{~N}^{7} \mathrm{O}^{6+}$ to $\mathrm{m} / \mathrm{z} 442.92$ in the treated sample were significantly increased compared with the control sample. The changes in isotopic abundance and mass peak intensities might be due to the changes in nuclei possibly through the interference of neutrino particles via the Trivedi Effect ${ }^{\circledR}$-Consciousness Energy Healing Treatment. The increased isotopic abundance ratio and peak area of the treated folic acid may increase the chemical bond strength, increase its stability, improve solubility, and bioavailability in the body. The new form of Biofield Energy Treated folic acid could be used for better designing novel pharmaceutical formulations that might offer better therapeutic response against poor growth, diarrhea, confusion, glossitis, depression, anemia, gray hair, mouth sores, swollen tongue, congenital deformities, embryonic defects, altered memory and brain function, leuco- and thrombocytopenia, cardiovascular disease, neural tube defects, and malignancies, risk of potentially developing allergic diseases, long-term risk of lower bone density, etc.

\section{Acknowledgment}

The authors are grateful to Sophisticated Instrumentation Centre for Applied Research \& Testing (SICART) India, Trivedi Science, Trivedi Global, Inc., and Trivedi Master Wellness for their assistance and support during this work.

\section{References}

1. Carmel R (2005) Folic Acid. In: Shils M, Shike M, Ross A, Caballero B, Cousins R (Eds.), Modern Nutrition in Health and Disease. Lippincott Williams \& Wilkins, Baltimore, MD.

2. Scholl TO, Johnson WG (2000) Folic acid: influence on the outcome of pregnancy. Am J Clin Nutr 71(Suppl 5): 1295S-1303S.

3. Guilland JC, Aimone-Gastin I (2013) Vitamin B9. Rev Prat 63(8): 1079, 1081-1084.

4. Owens J E, Clifford AJ, Bamforth CW (2007) Folate in Beer. J Inst Brew 113(3): 243-248.

5. Pobocik RS, Richer JJ (2002) Estimated intake and food sources of vitamin A, folate, vitamin C, vitamin E, calcium, iron, and zinc for Guamanian children aged 9 to 12. Pac Health Dialog 9(2): 193-202.

6. Whittaker P, Tufaro PR, Rader JI (2001) Iron and folate in fortified cereals. J Am Coll Nutr 20(3): 247-254.

7. Fenech M (2012) Folate (vitamin B9) and vitamin B12 and their function in the maintenance of nuclear and mitochondrial genome integrity. Mutat Res 733(1-2): 21-33.

8. Greenberg JA, Bell SJ, Guan Y, Yu Y (2011) Folic Acid Supplementation and Pregnancy: more than just neural tube defect prevention. Rev Obstet Gynecol 4(2): 52-59.

9. Allen LH (2008) Causes of vitamin B12 and folate deficiency. Food Nutr Bull 29(2): S20-34.

10. https://en.wikipedia.org/wiki/Folate.

11.https://pubchem.ncbi.nlm.nih.gov/compound/folic_ acid\#section=0dor.

12. Branton A, Trivedi MK, Trivedi D, Nayak G (2018) Evaluation of the physicochemical and thermal properties of the biofield energy healing treated ofloxacin. J Pharm Pharmaceutics 5(2): 80-87.

13. Trivedi MK, Branton A, Trivedi D, Nayak G, Panda P, et al. (2016) Evaluation of the isotopic abundance ratio in biofield energy treated resorcinol using gas chromatography-mass spectrometry technique. Pharm Anal Acta 7: 481

14. Branton A, Jana S (2017) The influence of energy of consciousness healing treatment on low bioavailable resveratrol in male Sprague Dawley rats. International Journal of Clinical and Developmental Anatomy 3: 9-15.

15. Trivedi MK, Mohan TRR (2016) Biofield Energy Signals, Energy Transmission and Neutrinos, American Journal of Modern Physics 5: 172-176.

16. Rubik B, Muehsam D, Hammerschlag R, Jain S (2015) Biofield Science and Healing: History, Terminology, and Concepts. Global Advances in Health and Medicine 4: 8-14.

17. Warber SL, Cornelio D, Straughn, J, Kile G (2004) Biofield energy healing from the inside. J Altern Complement Med 10(6): 1107-1113.

18. Movaffaghi Z, Farsi M (2009) Biofield therapies: biophysical basis and biological regulations? Complement Ther Clin Pr 15(1): 35-37.

19. Koithan M (2009) Introducing complementary and alternative therapies. J Nurse Pract 5(1): 18-20.

20. Barnes PM, Bloom B, Nahin RL (2008) Complementary and alternative medicine use among adults and children: United States, 2007. Natl Health Stat Report 12: 1-23.

21. Nayak G, Trivedi MK, Branton A, Trivedi D, Jana S (2018) Evaluation of the effect of consciousness energy healing treatment on the physicochemical and thermal properties of selenium. Journal of New Developments in Chemistry 2: 13-23. 
22. Nayak G, Trivedi MK, Branton A, Trivedi D, Jana S (2018) Evaluation of the physicochemical and thermal properties of chromium trioxide $\left(\mathrm{CrO}_{3}\right)$ : Impact of consciousness energy healing treatment. Research \& Development in Material Science 8: 1-6.

23. Nayak G, Trivedi MK, Branton A, Trivedi D, Jana S (2018) Evaluation of the physicochemical and thermal properties of consciousness energy healing treated polylactic-co-glycolic acid (PLGA). Journal of Food Science and Technology 5(3): 117-125.

24. Trivedi MK, Branton A, Trivedi D, Nayak G, Sethi KK, et al. (2016) Determination of isotopic abundance ratio of biofield energy treated 1,4-dichlorobenzene using gas chromatography-mass spectrometry (GC-MS). Modern Chemistry 4(3): 30-37.

25. Trivedi MK, Branton A, Trivedi D, Shettigar H, Nayak G, et al. (2015) Antibiogram typing of biofield treated multidrug resistant strains of Staphylococcus species. American Journal of Life Sciences 3(5): 369374

26. Trivedi MK, Branton A, Trivedi D, Shettigar H, Nayak G, et al. (2015) Antibiogram, biochemical reactions and genotyping characterization of biofield treated Staphylococcus aureus. American Journal of BioScience 3(6): 212-220.

27. Trivedi MK, Branton A, Trivedi D, Nayak G, Bairwa K, et al. (2015) Physical, thermal, and spectroscopic characterization of biofield energy treated murashige and skoog plant cell culture media. Cell Biology 3(4): 50-57.

28. Trivedi MK, Branton A, Trivedi D, Nayak G, Gangwar M, et al. (2015) Morphological and molecular analysis using RAPD in biofield treated sponge and bitter gourd. American Journal of Agriculture and Forestry 3(6): 264-270.

29. Trivedi MK, Patil S, Shettigar H, Mondal SC, Jana S (2015) The potential impact of biofield treatment on human brain tumor cells: A time-lapse video microscopy. J Integr Oncol 4: 141.

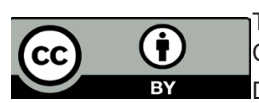

DOI:10.19080/ARR.2021.06.555684
30. Trivedi MK, Patil S, Shettigar H, Gangwar M, Jana S (2015) In vitro evaluation of biofield treatment on cancer biomarkers involved in endometrial and prostate cancer cell lines. J Cancer Sci Ther 7(7): 253257.

31. Schellekens RC, Stellaard F, Woerdenbag HJ, Frijlink HW, Kosterink JG (2011) Applications of stable isotopes in clinical pharmacology. Br J Clin Pharmacol 72(6): 879-897.

32. Muccio Z, Jackson GP (2009) Isotope ratio mass spectrometry. Analyst 134: 213-222.

33. Weisel CP, Park S, Pyo H, Mohan K, Witz G (2003) Use of stable isotopically labeled benzene to evaluate environmental exposures. J Expo Anal Environ Epidemiol 13(5): 393-402.

34. Rosman KJR, Taylor PDP (1998) Isotopic compositions of the elements 1997 (Technical Report). Pure Appl Chem 70(1): 217-235.

35. Smith RM (2004) Understanding Mass Spectra: A Basic Approach, Second Edition, John Wiley \& Sons, Inc.

36. Jürgen H (2004) Gross Mass Spectrometry: A Textbook. (2 ${ }^{\text {nd }}$ edn), Springer: Berlin.

37. Martins-Júnior HA, Wang AY, Alabourda J, Pires MAF, Vega OB, Lebre DT (2008) A validated method to quantify folic acid in wheat flour samples using liquid chromatography - tandem mass spectrometry. J Braz Chem Soc 19(5): 971-977.

38. Santesteban LG, Miranda C, Barbarin I, Royo JB (2014) Application of the measurement of the natural abundance of stable isotopes in viticulture: A review. Australian Journal of Grape and Wine Research 21(2): 157-167.

\section{Your next submission with Juniper Publishers will reach you the below assets}

- Quality Editorial service

- Swift Peer Review

- Reprints availability

- E-prints Service

- Manuscript Podcast for convenient understanding

- Global attainment for your research

- Manuscript accessibility in different formats

( Pdf, E-pub, Full Text, Audio)

- Unceasing customer service

Track the below URL for one-step submission https://juniperpublishers.com/online-submission.php 